PLASTIC SPHERES FOR IMPLANTATION INTO

TENON'S Caplule

\title{
PLASTIC SPHERES FOR IMPLANTATION INTO TENON'S CAPSULE IN THE FROST-LANG TYPE OPERATION FOR ENUCLEATION OF THE EYEBALL*
}

BY

\author{
R. E. Wright, C.I.E., M.Ch., Major (Temp.), I.M.S.
}

FOR many years I have used perforated solid glass necklace beads of various sizes for the above purpose. They were perhaps not so suitable as carbonized bone or gold basket spheres but were much easier to obtain than the former and far cheaper than the latter. Most of the other materials used for implantation have greater or lesser disadvantages; e.g., hollow glass spheres may burst, smooth unperforated spheres of any material are likely to migrate, and silver baskets caúse staining.

The advantage of a perforated glass bead was that it could be anchored with catgut to the muscles inside the capsule.

The technique of snare enucleation, or that of stripping the pedicle with a De Weltz spoon and clamping with the instrument made at my suggestion by Messrs. Down Bros., which I prefer, gives a good view of the capsule sleeve and muscle cone and an almost dry socket. In this the perforated sphere can be anchored readily by picking up bites of opposing muscles a short distance back from where they were divided, with a catgut suture running through the sphere.

It occurred to me some time ago that methyl methacrylate resin spheres perforated in 2 diameters at right angles, and fluted on the surface in a sort of basket work pattern, might be better than perforated glass beads and even easier to obtain. Lt.-Col. S. H. Woods, Army Dental Corps, kindly had such spheres made for me by the No. 1 Dental Laboratory, Aldershot.

They were anchored to the superior and inferior recti by gut passing through the vertical tunnel, and to the lateral muscles by way of the horizontal tunnel. These sutures were tied over the top of the globe; the usual purse string catgut suture was then passed round the mouth of the bag, picking up alternate bites of Tenon's capsule and cut muscle extremities, and tied off. The fluting of the globe is intended to supplement the fibrous tissue anchorage which eventually takes place.

The resin spheres first used produced an unexpected and extensive non-inflammatory oedema of the lids and cheek. This undesirable reaction occurred on several successive occasions. Messrs. Down Bros. suggested that the tissue reaction might be

* Received for publication, A ugust 5, 1944. 
due to using unsuitable plastic and offered to make up some spheres in material proved to be inert. The firm kindly supplied me with some $17 \mathrm{~mm}$. spheres as illustrated. These have been

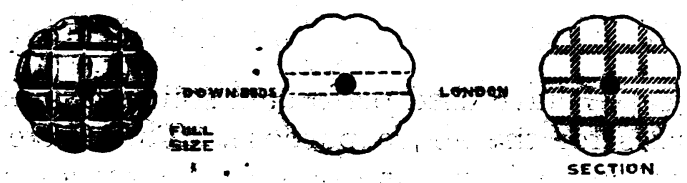

used on fout occasions up to date; only trivial post eperative tissues reaction was noted. One patient seen a year after the implantation was made had a perfect socket with good movement of his double shell (reform) prosthesis, without any history of intervening irritation.

In view of all the trouble which a bad socket can give rise to, as emphasised by one's experience in the present war emergency, it seems well worth while to take pains to give every patient that is subjected to enucleation the opportunity of having a good socket. One should aim at a convex movable stump, covered by smooth conjunctiva as free from scar tisstue rucking as possible. This may be obtained by careful limbal incision of the conjunctiva, adequate undermining, a good implant, and closure of the cleancut conjunctival wound by accurate apposition of its edges.

Such sockets are worth treating with respect and nothing but a double-shell (reform prosthesis) or a carefully filled plastic prosthesis should be used. A single-shell prosthesis is very liable to produce contracted socket, an even greater evil in military than in civil life. Since writing the above it has come to my notice that the idea of using plastic spheres is not new. I understand they have been used in Canada and perhaps elsewhere.

The pattern described is possibly an innovation; at all events the perforations are of considerable importance.

\section{THE LOCAL APPÍICATION OF PENICILLIN} SOLUTION TO THE EYE*

BY

\section{- R. E.'WRIGHT, C.I.E., M.Ch., Major (Temp.), I.M.S.}

-IF it is desired to apply the solution to the conjunctiva and cornea by frequent instillation tather than by some form of contact chamber, which is not always well borne, the following simple device may be employed. 